\section{Privatizing and internationalizing violence}

Herbert Wulf

$\mathrm{T}$ he history of contemporary wars and violent conflict reveals two new trends: the privatization of violence and international interventions to stop wars. ${ }^{1}$ First, privatization of violence: The number of armed non-state actors engaged in wars and violent conflicts has decidedly increased during the last two decades. Armed non-state actors such as warlords, militias, rebels, para-military groups, and gangs fight for their own political or economic interests. This process has been classified as bottom-up privatization in which armed non-state actors spread violence, create insecurity, and contribute to the failure of states. At the same time, governments contract more and more technical or other logistic services to private military companies in order to assist the regular armed forces in wars. In exceptional cases they even hire companies for combat operations - a process called top-down privatization or outsourcing of military functions. ${ }^{2}$ Many governments in conflictprone areas, in countries with failed or weak statehood as well as in many postconflict societies are no longer capable of guaranteeing law and order. Their police and military forces are too weak, too corrupt, or unwilling to exercise the rule of law and the state monopoly of violence. ${ }^{3}$ Unarmed non-state actors operate in this locus of weak statehood uncontrolled and unrestricted. This type of private use of violence offers attractive economic gains.

The history of contemporary wars and violent conflict reveals two new trends: the privatization of violence and international interventions to stop wars.

The armed forces of many countries in the world have demobilized millions of soldiers since the end of the Cold War. Yet today these forces are increasingly burdened with various deployments in conflict, war and post-war, such as in the Balkans, in Africa, Afghanistan, and Iraq. They have consequently come to depend more and more on private military companies for logistic support, training, repair and maintenance of weapons systems and other military equipment, for the collection of intelligence information, for interrogation of prisoners of war, and for supplying mail, food, and clean uniforms. Private companies of all sizes are active worldwide in pre-war preparation, in war, and in post-war programs. One problem with these developments is that they occur largely outside the control of parliaments and only partially under the oversight of governments. The boom in the creation of private military companies and the significant growth in their turnover is part of a general trend to privatize state functions.

The two forms of privatization - bottom-up and top-down - are fundamentally different, and partly contradictory, since privatization in violence markets is always exercised without the consent of governments and usually against their explicit policy, while outsourcing of military tasks to private military companies is a government planned process. These forms of privatization are not always easy to separate. Warlords, rebels, and similar groups occasionally clash with private military companies, particularly when besieged governments turn to these companies for protection, for example in Iraq or Afghanistan, or when governments deploy militias for their defense, as was the case for example in Zaire under President Mobuto shortly before his fall.

Second, international interventions: The international community has progressively tried to counter the outbreak and fighting of wars through concerted efforts to intervene, if necessary by military means, with and without U.N. mandates. There is a general trend in recent years of political decisions to engage in international interventions, e.g., military missions of peacekeeping, peace enforcement, peace building, or other types of international military or civil-military interventions. Such international interventions, it is argued by its proponents, are needed because of humanitarian concerns, for example to prevent genocide, ethnic cleansing, or other gross human rights violations, to promote democracy or a change of regime, and to facilitate nation-building. The "responsibility to protect" has become a widely accepted norm. ${ }^{4}$ In these cases the military is supposed to act as a stabilizing factor.

As a result, armed forces are operating more and more jointly as "Blue Helmets," as "coalitions of the willing," or as military alliances. These international operations affect the organization of the military. International interventions necessitate not only new weapons and equipment but also structural changes within the armed forces. The military that is traditionally geared to the nation-state must now orient its structure internationally. In fact, nationally organized armed forces are now outdated, given these new international tasks. But considerations of prestige and pride, and national political and economic interest, are a barrier to establishing a truly integrated international armed force.

Both, privatization of violence and international interventions, have important effects on executing the monopoly of violence. For more than three centuries, since the Peace of Westphalia, the monopoly of force has been held by the nation-state, a state with a clearly defined territorial space - though not in all parts of the world. This concept of the monopoly of violence is now fundamentally questioned for a variety of reasons, including the privatization and internationalization of violence. Nowadays, the authority for decisionmaking about the deployment of troops has been progressively delegated to international organizations. The instruments and methods to control the armed forces and other institutions of the state monopoly of force are a prerequisite for their legitimate use. This has largely been the case within the nationstate. However, if the nation-state changes so fundamentally due to internationalization and globalization, instruments for control need to be developed at a global level. This is presently not the case and it is not foreseeable that this gap 
in democratic control will soon be closed. International democratic control of the armed forces has not developed in parallel to the international military interventions. A culture of accountability of the decisionmakers at the global level is glaringly absent. Democratic control, if exercised at all, takes place at the national level but not internationally. ${ }^{5}$ This undemocratic character of international relations and international law throughout history makes the process of democratizing this system extremely difficult.

Why should - and actually can - a life-and-death question such as war and peace in the world be excluded from the democratic decisionmaking process? The democratic control of internationalized armed forces is more complex than of national forces. Tasking private military firms with military jobs complicates the democratic control even more or might make it impossible in certain situations. However, armed forces engaged in international interventions in the name of the defense of human rights, the promotion of democracy, and the prevention or ending of war are only credible if they themselves operate on the basis of effective democratic control. Otherwise, there is the danger of misusing the armed forces for purposes other than humanitarian.

Causes and motives for outsourcing

Privatization of military and security services embraces a wide variety of different concepts and developments. Privatization, occasionally also called commercialization or outsourcing includes - willingly or unwillingly - giving up part of a state's authority in exercising the monopoly of violence.

The first type, the bottom-up privatization, in which representatives of the state system are occasionally accomplices, describes activities of non-state actors. These non-state actors, who can also be classified as "violence entrepreneurs" create a situation of insidious insecurity. They are often the cause for chaotic or lawless situations or even the collapse or failure of states, and are directly responsible for the loss of the state monopoly of violence. In many cases where the U.N. intervened, such as in Liberia, Sierra Leone, the Democratic Republic of Congo, East Timor, Kosovo, Haiti, and Afghanistan, these non-statutory armed forces are the cause for the violent conflict and/or the main hindrance to ensure sustainable peace.

The second type of privatization, top-down, is deliberately planned and implemented by governments. The aim is to outsource traditional military and state functions to private companies. They offer a wide range of services: they work for armed forces in war, but also for non-state institutions such as international agencies, humanitarian organizations in post-conflict societies, for governments in their fight against rebels or insurgents as well as for multinational companies.

The present discussion about the activities of those private military firms sometimes creates the impression as if this is an entirely new phenomenon. But in the past governments have already entrusted companies or other private actors with diverse military tasks. The most prominent example is weapon manufacturing. Privatization in the military sector is not new; new is that a wider spectrum of traditional military tasks is outsourced today.

Governments outsource military jobs mainly to compensate for reduced military capabilities and for economic reasons. According to the dominant economic theory, the market is better qualified to handle these functions more efficiently than the armed forces themselves. The causes and motives to order services at private military companies are manifold and sometimes overlap. At least eight military, economic, political, and ideological reasons for commercialization or privatization can be delineated. First, on the supply side, there are vast capacities of highly qualified military experts who no longer find employment in the armed forces. They are now looking for new jobs and find them in the private military companies. Second, at the same time some armed forces are over-burdened by the increasing number of military interventions abroad. Outsourcing of military missions is a reaction to bottlenecks in the availability of specialized troops. Third, armed forces tend to use ever more modern equipment. They are, however, no longer in a position to use and maintain all these high-tech systems; they depend on the technical service of expert companies. Fourth, especially weak or besieged governments without strong armed forces purchase such services. Fifth, the demand for U.N. peace missions has always been larger than what member states offer in troops and other resources. This situation strengthened the role of private security and military companies to support or even replace the state troops. Sixth, the intensified demand for armed forces in various deployments related to the "war against terror" contributed to the over-stretch of armed forces. Thus, governments try to complement or replace the armed forces' missions by using the private sector. Seventh, given public opinion at home, it is more attractive for some governments to task military firms with the intervention job rather than the armed forces. Public awareness and the criticism when body bags return home have an effect on government decisionmaking. It is less eye-catching to send contractors than uniformed soldiers. Eighth, the concept of a "lean state" is central for this development. Many state functions - civilian as well as military - are outsourced in order to find market solutions which are more cost effective. The neoliberal concept of the lean state has not stopped at the gates of military bases, and even sensitive military functions are privatized.

However, the private sector still needs to produce the empirical evidence that it can contribute to solving some of the budgetary difficulties of the defense sector or do the job more efficiently. Increasing privatization and delegation of public missions to the private sector has certainly been of great economic benefit in a number of areas. Economic success in privatizations - independent of which part of the public sector 
is privatized - depends on at least three conditions. ${ }^{6}$ First, true and sustained competition must be operable; competition is essential to prevent companies from realizing monopoly profits. Second, government or its agencies must have a clear understanding of what kind of services are expected, and they must be able to articulate their demand. Third, control and verification mechanisms must be in place.

The results of evaluations of numerous contracts in the defense sector, for example by the U.S. Government Accountability Office, show that these conditions are not always guaranteed. So-called blanket-purchase agreements are often signed with a limited number of a few big companies, often without public bidding. Long-term and open-ended blanket-purchase agreements do not include clearly defined services. On the contrary, to avoid public bidding and to be able to quickly request services and make use of the know-how of companies, the Pentagon, for example, prefers open and vaguely formulated contracts. Such contracts usually evolve into a bilateral monopoly, with a monopolist each on the demand and the supply side. The capacities in the defense ministries to oversee the private military companies are completely inadequate. Ironically, private military companies have been contracted to oversee other private military companies while another company was tasked to write the government guidelines for defense ministry outsourcing. ${ }^{7}$

Deployment of private military companies is not without tension because they need to pursue two at least partially competing principal concepts: guaranteeing security by the public sector and the profit motive of these companies. The public good "security" and the private good "economic gain" can be in competition with each other or even be contradictory. To avoid the risk of losing assets, companies have in certain cases decided against providing security by military means. For instance, during the Ethiopia and Eritrea war at the end of the 1990s, Ethiopia leased a small but modern air force from the Russian aircraft manufacturer Sukhoi, including modern Su-27 fighter jets with pilots and maintenance crews. This air force flew hardly any sorties during the war. Eritrea had equally hired Ukrainian aircraft and pilots, but the companies on both sides did not want to risk their assets and the pilots' live. This risk avoidance strategy of private companies could possibly emerge as a new and completely unexpected barrier to the engagement in fighting. In contrast, the profit motive of the companies could function as a conflict accelerator.

The role of the state - mercantilism revisited

Privatization of violence and internationalization of force correlate closely with the dominant economic system and power structure, especially with the ongoing globalization of society and liberalization of markets. The key to the modern "Westphalian" nation-state is the monopoly of legitimate force which includes the dissolution of private armies and de-privatizing the use of violence. ${ }^{8}$ This concept is questioned, or at least undermined, by the notion of outsourcing military and police functions. Furthermore, globalization deemphasizes the nation-state as the key actor in the international system. Globalization liberates powerful economic forces; it embraces most countries of the world but also excludes millions of people from the benefits of economic growth. It integrates and connects states and people and fractures them at the same time. The erosion of the nation-state is an extreme manifestation of globalization as it increasingly leads to a shift of the loci of authority away from the nation-state toward the global and the local level, leading to a diversity of authority relationships. ${ }^{9}$ As a result, security can no longer (if it ever could in many areas of the world) be guaranteed by the nation-state.

At the same time, however, promoting nation-building and a liberal, deregulated market economy has become the lynchpin of international interventions, peacekeeping, and reconstruction programs. It seems somewhat paradox to prioritize the creation or rebuilding of central state authority and institutions - despite the socalled Washington consensus which

calls for a reduced role of the state in development - during a period of history when globalization reduces the room for decisions at the nation-state level. The pendulum for the perception of state institutions has now swung in favor of good governance in which the international community promotes effective state institutions and a functional and legitimized state. ${ }^{10}$ On the one hand, the dominant economic theory largely ignores the privatization of violence from below, despite the fact that the criminal sector is a growth industry. Official economic statistics hardly recognize this fact. ${ }^{11}$ On the other hand, the concept of the lean state functions as the ideological pattern for privatizing military and police tasks by claiming that the private sector is more efficient. $^{12}$

Mercantilism was the general and widely accepted economic doctrine during the period from the 16th to the 18th century, the time when the state monopoly of violence developed in Europe after the Peace of Westphalia. Today's economic policy and instruments are largely a mirror image of the mercantilist period. During the time of Jean-Baptiste Colbert (1619-1683, and Finance Minister to France’s Louis XIV) and Robert Walpole (1676-1745, and British Prime Minister), the aim was to increase the wealth of the nation. Wealth meant power. Trade would not only enrich the individual merchant but increase the power of the state, too. Economic development was conceived as a zero sum game in which the expansion of trade and the control of foreign territories could only be accomplished at the expense of competing nations. ${ }^{13}$ To achieve this goal, the state introduced unprecedented intervention mechanisms and began to regulate economic affairs - both foreign trade and domestic economic development. In contrast today, deregulating the economy and liberalizing trade is 
supposed to benefit all participating actors, thus a win-win-situation. During mercantilism, the political rivalries of the past became systematized to economic competition and conflict of state power with many wars among the European nations.

Already during the absolutist period, the various princely states had realized their need for secure finances to feed and pay their troops. The mercantilist states' ambitions, their need for building powerful navies and armies, to man them and equip them with ships and weapons, created new and unprecedented demands on the state budget. As a result, a state bureaucracy with war ministries and departments for revenue collection were invented and created. The infrastructure was improved to organize the logistics for the armies. The size of the armed forces grew dramatically. Louis XIV increased his army from 30,000 soldiers in 1659 to 97,000 in 1666 and to 350,000 in $1710 .{ }^{14}$ New standards for training and discipline of the troops were introduced; military bases, military hospitals, parade places, and military depots were constructed. The period of mercantilism saw the creation of standing armies, recruited mainly from the state's own population; the war entrepreneurs, the mercenaries and condottieri, typical for the period of the Thirty Year war in Europe, gradually came under the control of the state. Civil servants took control over the war system and its funding while military officers' tasks were limited to strictly military matters. Monopolization and bureaucratization of military power in the hands of the state was typical for the history of nation-building in Europe. The growth of state power and resources with permanent forces was unparalleled. ${ }^{15}$

The comparison of the economic concept of the mercantilist period and today's neoliberal economic concept illustrates some of the marked contrasts. They are most significantly illustrated through the instrument of state intervention in the mercantilist period versus deregulation and privatization of today, and in the realm of national orientation versus globalization. The state monopoly of force emerged in the mercantilist period; individuals were forced to give up their weapons; private armies were dissolved and war entrepreneurs ran out of business due to the creation of standing mass state forces. Today, neither the monopoly of force nor the existence of national armed forces is conceptually questioned. But outsourcing of military functions reduces the state's role in exercising the monopoly of force. Privatization of military functions, the delegation of a central state function to private actors, the boom in private military companies, and more generally the privatization of security entails the danger of undermining the state monopoly of force, which has been considered as an important civilizing factor in the history of Europe. A number of governments enforce this process, while experimenting with the still to be proven argument that the private sector is more efficient in the area of military missions as well.

\section{Beyond the nation-state}

Deployment of private companies has a deep impact on how the state monopoly of violence is exercised and controlled. An important consideration is that these companies are not accountable to parliament or the public. While government is held accountable by parliament, private companies are responsible only to their shareholders and clients. This is precisely the reason why some governments want to make use of private companies. Parliamentary control can thus partially be avoided by the executive. A case in point is the engagement of private military companies in the anti-drug campaign in Colombia on behalf of the U.S. government. The government took this decision after Congress ruled that the U.S. military could not be deployed for that task.

The major impact of internationalizing military functions is a fundamental change of the role of the military in its relation to the nation-state and the long-term effects for the state monopoly of force. Globalization has changed the
Private military companies are not accountable to parliament or the public. This is precisely the reason why some governments want to make use of them. basic concept of the nation-state.

De-nationalization and a reduced role of the state can be observed in many economic, social, and cultural areas. In most cases national governments can no longer take decisions regarding war and the use of force. There is a real danger that the state instruments of force fall into the hands of non-state actors like criminal gangs, insurgents, and militias or that they will be handed over to privately operating companies. The trends to privatize and internationalize security exacerbate the already pressing problem of insufficient parliamentary oversight of the armed forces. However, it has been rightly emphasized that "the crux of the issue is not how force is organized (i.e., public or private) but how it is organized (i.e., regulated)." ${ }^{16}$ At the international level it is often unclear under whose control the internationalized armed forces operate, and democratic oversight is only marginally developed.

Three political and legal areas are of great importance for the future development of security and peace and the regulation of force. First is the regulation and the strict legal control of private military companies so as to overcome the legal black hole in which they presently operate. ${ }^{17}$ A comprehensive prohibition seems impossible, not the least because of legal and administrative difficulties of implementation. Selfregulation of the industry seems inadequate since the "black sheep" within the industry would not observe the self-regulation mechanism anyway. The regulation of companies can be addressed at different levels, ranging from a reformed Geneva Convention, to registration and licensing of companies - as is done, for example, in arms export regulation - to international transparency and verification methods.

A second arena pertains to overcoming the democratic deficit. ${ }^{18}$ At the national level parliaments can use their legislative function and budgetary powers as an effective instrument to strengthen their role in influencing or preventing executive decisions. While this is not uncommon with regard to the deployment of troops, 
contracts with military firms and deployment of contract personnel is hardly on the agenda of parliaments. However, the established although often inadequate control mechanisms at the national level are being complicated when international missions are decided upon. The national control instruments are often unsatisfactory for this purpose. International law and practice needs to be reformed to cover the new trends of privatization of violence and internationalization of interventions.

A third point regards the reforming of the state monopoly of force. Reconstructing the monopoly of violence in post-conflict situations is not just about re-establishing state monopoly of violence. A more comprehensive approach is necessary to establish rules and regulations for the use of force. Instead of addressing almost exclusively, as it is presently done by external actors, the level of the nation-state, it has been suggested to establish a carefully crafted division of labor in exercising the monopoly of violence at the global (U.N.), regional (regional organizations), nation-state, and local level. ${ }^{19}$ As a result of increasing interdependence and globalization, the nationstate has lost or transferred part of its sovereignty to other entities: to the top (to supranational or multilateral organizations) and down to lower levels (such as local and district associations). These realities should also be reflected in the monopoly of force. Given the globalized world, with porous or non-existent nation-state borders, with failing or collapsed states, and with asymmetric zones of insecurity, the future lies not necessarily in the establishment of a nation-state monopoly, but rather in a multi-level public monopoly of violence at the local, national, regional, and global level. To create such a system might seem utopian. However, a multi-level public monopoly of force comes closer to the present reality of the international system than the state-centric nation-state system since it addresses these different levels of political decisionmaking.

\section{Notes}

Herbert Wulf is the former Director of the Bonn International Center for Conversion (BICC). He is a consultant on capacity building in disarmament to the United Nations Development Program in Pyongyang, Democratic Peoples’ Republic of Korea, and may be reached at wulf.herbert@web.de.

1. This article draws on Wulf (2005).

\section{Mandel (2001).}

3. I use the terms "monopoly of violence” and "monopoly of force” interchangeably.

4. See International Commission on Intervention and State Sovereignty (2001); United Nations High-level Panel on Threats, Challenges and Change (2004). Also see Brauer (2006).
5. See Ku and Jacobson (2003); Born and Hänggi (2004).

\section{Markusen (2003).}

7. See Wulf (2005, pp. 186-191).

8. Weber (1992 [1919], pp. 157-252).

9. Mason (2005).

10. Debiel (2005).

11. Lock (2004).

12. Singer (2003, p. 66) calls this "the power of privatization and the privatization of power."

13. Colbert wrote: "France ... could rise to power and wealth only on the ruins of her rivals.” Quoted in Howard (1976, p. 46).

14. Kennedy (1987, p. 88).

\section{Tilly (1990).}

16. Brauer (forthcoming). Quote from p. 2 of draft chapter available at http://www.aug.edu/ sbajmb/paper-PMCs.pdf [accessed 24 August 2006].

17. Schreier and Caparini (2005).

18. Ku and Jacobson (2003); Born and Hänggi (2004).

19. These proposals are detailed in Wulf (2006).

References

Born, Hans and Heiner Hänggi, eds. 2004. The Double Democratic Deficit: Parliamentary Accountability and the Use of Force under International Auspices. Aldershot, UK: Ashgate.

Brauer, Jurgen. Forthcoming. "Private Military Companies: Markets, Ethics, Economics,” chapter in Andrew Alexandra, Marina Caparini, and Deane-Peter Baker, eds. Private Military Companies: Ethics, Theory, and Practice. Brauer, Jurgen. 2006. “Theory and Practice of Intervention.” The Economics of Peace 
and Security Journal, Vol. 1, No. 2, pp. 17-23. http://www.epsjournal.org.uk.

Debiel, Tobias. 2005. “Dealing with Fragile States.” ZEF-Discussion Papers on Development Policy, Nr. 101. Bonn: Zentrum für Entwicklungsforschung.

Howard, Michael. 1976. War in European History. Oxford: Oxford University Press. International Commission on Intervention and State Sovereignty. 2001. "The Responsibility to Protect: Report of the International Commission on Intervention and State Sovereignty.” Ottawa: International Development Research Centre. http://www.iciss.ca/pdf/Commission-Report.pdf [accessed 24 August 2006].

Kennedy, Paul. 1987. The Rise and Fall of the Great Powers. New York: Random House.

Ku, Charlotte and Harold K. Jacobson, eds. 2003. Democratic Accountability and the Use of Force in International Law. Cambridge: Cambridge University Press.

Lock, Peter. 2004. "Gewalt als Regulation: Zur Logik der Schattenglobalisierung," pp. 40-61 in Sabine Kurtenbach and Peter Lock, eds. Kriege als (Über)Lebenswelten. Bonn: Dietz Verlag.

Mandel, Robert. 2001. “The Privatization of Security.” Armed Forces \& Society, Vol. 28, No. 1, pp. 129-151.

Markusen, Ann R. 2003. "The Case Against Privatizing National Security." Governance, Vol. 16, No. 4, pp. 472-478.

Mason, Ann C. 2005. "Constructing Authority Alternatives on the Periphery: Vignettes from Colombia.” International Political Science Review, Vol. 26, No. 1, pp. 37-54.

Schreier, Fred and Marina Caparini. 2005. "Privatising Security: Law, Practice and Governance of Private Military and Security Companies.” Occasional Paper No. 6. Geneva: Geneva Centre for the Democratic Control of the Armed Forces. http://www.dcaf.ch/_docs/op06_privatising-security.pdf [accessed 23 August 2006].

Singer, Peter W. 2003. Corporate Warriors. The Rise of the Privatized Military Industry. Ithaca, NY: Cornell University Press.

Tilly, Charles. 1990. Coercion, Capital, and European States. Oxford: Blackwell.

United Nations High-level Panel on Threats, Challenges and Change. 2004. A More Secure World: Our Shared Responsibility.” New York: Report of the High-level Panel on Threats, Challenges and Change.

Weber, Max. 1992 [1919]. Politik als Beruf. In Max Weber, Gesamtausgabe, Vol. 17. Tübingen: J.C.B. Mohr/Paul Siebeck.

Wulf, Herbert. 2005. Internationalizing and Privatizing War and Peace. New York: Palgrave Macmillan.

Wulf, Herbert. 2006. “Good Governance Beyond Borders: Creating a Multi-level Public Monopoly of Legitimate Force.” Occasional Paper No. 10. Geneva: Geneva Centre for the Control of the Armed Forces. http://www.dcaf.ch/_docs/ op10_good_governance_beyond_borders.pdf [accessed 23 August 2006]. 